\title{
CTLA-4 gene polymorphisms and risk of idiopathic recurrent pregnancy loss in a Tunisian population
}

\author{
Safia Messaoudi, Illham Houas, Khadijah Yaseen, Mariem Dandana, Touhami Mahjoub \\ From 2nd International Genomic Medical Conference (IGMC 2013) \\ Jeddah, Kingdom of Saudi Arabia. 24-27 November 2013
}

\section{Background}

An aberrant regulation of immunological, metabolic, vascular and endocrine processes leads to obstetric complications, including recurrent pregnancy loss (RPL) [1]. Cytotoxic T lymphocyte-associated antigen 4 (CTLA-4) is a negative regulator of $\mathrm{T}$ cell activation [2] expressed in placental fibroblasts and may modulate peripheral selftolerance of the allogenic fetus $[3,4]$. It is a stimulatory molecule involved in T-cell activation at the maternalfetal interface in women with unexplained pregnancy loss $[5,6]$. In this study, we investigate the possible associations of Cytotoxic T lymphocyte-associated antigen 4 (CTLA-4) gene polymorphisms with idiopathic recurrent pregnancy loss (RPL).

\section{Materials and methods}

We investigated the association of the CTLA-4 gene single nucleotide polymorphisms (SNPs) - $318 \mathrm{C} / \mathrm{T}$ (rs5742909), +49A/G (rs231775), and CT60 A/G (rs3087243), by TaqMan assays in analysis in 470 Tunisian women comprising 235 RPL cases and 235 multi-parous controls. The association of CTLA-4 alleles, genotypes, and haplotypes with RPL was evaluated by Fisher's exact test and regression analysis.

\section{Results}

The CTLA-4 variants rs5742909, rs231775, and rs3087243, were in Hardy Weinberg equilibrium, and low linkage disequilibrium was noted between the three studied SNPs. The frequency of rs $231775 \mathrm{G}$ allele $(\mathrm{P}=0.04)$, but not rs3087243 $\mathrm{G}$ allele $(\mathrm{P}=0.61)$ or rs5742909 $\mathrm{T}$ allele $(\mathrm{P}=1)$, was higher in RPL cases than in control women. Significant differences in

\footnotetext{
* Correspondence: safsafsophie@gmail.com

Laboratory of Human Genome and Multifactorial Diseases, Faculty of Pharmacy of Monastir, University of Monastir, Tunisia
}

the distribution of rs231775 $(\mathrm{P}<0.02)$, but not rs5742909 $(\mathrm{P}=0.21)$ or $\operatorname{rs} 3087243(\mathrm{P}=0.49)$ genotypes were seen between cases and controls, and only rs 231775 showed a significant association with RPL, with increments of 1.74 in disease risk seen for heterozygous carriers. Only rs231775 (+49/A/G), previously shown associated with the immuno-pathogenesis of RPL, and it confers susceptibility to RPL in Chinese population [5] and North Indian Women [7], was significantly associated with RPL. Among the six three-locus CTLA-4 haplotypes constructed (rs5742909/rs231775/rs3087243), increased frequency of CGA ( $\mathrm{P}=0.0046)$, and CAG $(\mathrm{P}=0.036)$ haplotypes were seen in RPL cases, thus conferring disease susceptibility nature to these haplotypes.

\section{Conclusions}

The rs231775 AG genotype and CGA and CAG haplotypes may contribute to RPL development in a Tunisian Population.

Published: 2 April 2014

\section{References}

1. Baek KH: Aberrant gene expression associated with recurrent pregnancy loss. Mol Hum Reprod 2004, 10(5):291-7.

2. Bashyam H: CTLA-4: From conflict to clinic. J Exp Med 2007, 204(6):1243.

3. Anjos SM, Polychronakos C: Functional evaluation of the autoimmunityassociated CTLA-4 gene: the effect of the (AT) repeat in the 3'untranslated region (UTR). J Autoimmun 2006, 27(2):105-9.

4. Kaufman KA, Bowen JA, Tsai AF, Bluestone JA, Hunt JS, Ober C: The CTLA-4 gene is expressed in placental fibroblasts.MHR: Basic science of reprod. Medicine 1998, 5(1):84-87.

5. Wang $X$, Lin $Q, M a Z$, Hong $Y$, Zhao A, Di W, Lu P: Association of the A/G polymorphism at position 49 in exon 1 of CTLA-4 with the susceptibility tounexplained recurrent spontaneous abortion in the Chinese population. Am J Reprod Immunol 2005, 53(2):100-5.

6. Wang X, Ma Z, Hong Y, Lu P, Line Q: Expression of CD28 and cytotoxic $T$ lymphocyte antigen 4 at the maternal-fetal interface in women with 
unexplained pregnancy loss. International Journal of Gynecology \&

Obstetrics 2006, 93(2):123-129.

7. Gupta, et al: Association of CTLA-4 and TNF-a polymorphism with recurrent miscarriage among North Indian women. Cytokine 2012, 60(2):456-62.

doi:10.1186/1471-2164-15-S2-P11

Cite this article as: Messaoudi et al:: CTLA-4 gene polymorphisms and risk of idiopathic recurrent pregnancy loss in a Tunisian population. BMC Genomics 2014 15(Suppl 2):P11.

Submit your next manuscript to BioMed Central and take full advantage of:

- Convenient online submission

- Thorough peer review

- No space constraints or color figure charges

- Immediate publication on acceptance

- Inclusion in PubMed, CAS, Scopus and Google Scholar

- Research which is freely available for redistribution

Submit your manuscript at www.biomedcentral.com/submit
Ciomed Central 